\title{
Ambient Temperature Associated Variations In Serum Urea And Creatinine In Marwari Goats
}

\author{
Gurdeep Kour $^{1}$, Nalini Kataria ${ }^{2}$, Ninad Sahebrao Lawhale ${ }^{3}$ \\ ${ }^{1}$ (Department of Veterinary Physiology, Khalsa College of Veterinary and Animal Science, Amritsar, India) \\ ${ }^{2}$ (Department of Physiology, College of Veterinary and Animal science, Bikaner, India) \\ ${ }_{3}^{3}$ (Department of Veterinary Pathology, Khalsa College of Veterinary and Animal Science, Amritsar, India)
}

\begin{abstract}
The present investigation was carried out on 540 apparently healthy Marwari goat of either sex, between 5 months to 4 years of age, to assess ambient temperature associated variations in serum metabolites of hepatic functions during moderate (October and November), hot (May and June) and cold (December and January) ambient temperature periods. In each ambient temperature period 180 blood samples were collected and the animals were grouped into male (90) and female (90). Further each group was divided according to age as 5-10 months (30 male and 30 female); $1-2$ years (30 male and 30 female) and 2.5-4 years (30 male and 30 female). Serum metabolites of hepatic functions included in the study were urea and creatinine and the overall mean values were $5.62 \pm 0.20 \mathrm{mmol} / \mathrm{l}(3-14 \mathrm{mmol} / \mathrm{l})$ and $94.97 \pm 2.90 \mu \mathrm{mol} / \mathrm{l}(55-153 \mu \mathrm{mol} / \mathrm{l}) \mathrm{respectively.} \mathrm{The}$ mean value of serum creatinine was significantly $(p \leq 0.05)$ higher during hot and non significantly higher $(p>0.05)$ during cold ambient temperature periods in comparison to overall moderate mean values, respectively. In each ambient temperature period the sex effect was significant $(p \leq 0.05)$ for both metabolites serum urea and serum creatinine, the values were higher in male animals. In each ambient temperature period the age effect was significant ( $p \leq 0.05)$ for both the metabolites, serum urea and serum creatinine the values being highest in the animals of 2.5-4 years of age. The present study indicated that extreme ambience can stimulate the liver of the animals of both the sexes and all age groups, which was reflected in the form of increased activity metabolites in the serum.
\end{abstract}

Keywords : Ambient temperature, Marwari goat, Serum, urea, creatinine

\section{Introduction}

Different regions in most parts of the world have different climates, and the major climatic variables, like temperature, humidity, rainfall and solar radiation affect livestock. In general animals are drastically affected at all levels of their organization by any change in their thermal surroundings and the processes of adaptation of organisms to seasonal changes involve variation in every aspect of physiology [1]. Temperature variations can affect productivity and resistance to infectious diseases and produce economical losses to animal owners [2].

The variations in the values of metabolites can occur due to climatic conditions, sex and age. Knowledge of these variations is imperative for a clinician to interpret the results for thorough investigation of an animal. The serum metabolite profile helps in assessing the metabolic status of the body. Stress goaded cortisol rise, may be due to disease or environment, affects carbohydrate, protein and fat metabolism [3]. Since the liver is the hub of metabolic processes, the variations in these matabolites depict hepatic functions fairly in clinical cases. These include total proteins, cholesterol, total fatty acids, glucose, urea and creatinine, reasonably representing the metabolism.

\section{Materials And Methods}

The study was carried out on five hundred and fourty apparently healthy Marwari goat of either sex, between 5 months to 4 years of age which were screened to determine ambient temperature associated variations in serum metabolites of hepatic functions.

Blood samples were collected during slaughtering (jugular vein) from private slaughter houses (Bikaner, Rajasthan). It was carried out in morning hours during moderate, hot and cold ambient temperature periods. Blood was collected directly into the clean, dry test tubes without any anticoagulant in duplicate. After collection of the blood, test tubes were kept in the slanting position for 30 minutes and blood was allowed to clot. Then the clot was separated from the walls of the each test tube with the help of sterilised stainless steel wire and then each test tube was centrifuged at $3000 \mathrm{rpm}$ for 10 minutes. Supernatant clear serum was pipetted out into sterilised plastic vials. Only non-haemolysed serum samples were used.

The total experiment was divided into three periods:

I. Period-I (Moderate ambient temperature, $34.34 \pm 0.26^{\circ} \mathbf{C}$ ) / Control period) (October and November). This serves as control period. 
II. Period-II (Extreme cold ambient temperature, $6.83 \pm 0.30{ }^{\circ} \mathbf{C}$ ) (December and January). The results of the period were compared with that of control period (moderate).

III. Perriod-III (Extreme hot ambient temperature, $42.31 \pm 0.32{ }^{\circ} \mathbf{C}$ ) (May and June). The results of this period were compared with that of control period (moderate).

The following parameters were analyzed to achieve the objectives. Serum metabolites of hepatic functions:

i. $\quad$ Urea (It was determined by diacetyl monoxime method of Natelson [4].

ii. $\quad$ Creatinine (It was determined by the method of Bonsnes and Taussky [4].

The statistical analysis of the data collected was done [5].

\section{Results And Discussion}

The present investigation was carried out on 540 apparently healthy Marwari goat of either sex, between 5 months to 4 years of age, to assess ambient temperature associated variations in serum metabolites of hepatic functions. Mean \pm SEM values of serum urea, creatinine and total proteins are presented in Table 1 .

\subsection{Urea}

The overall mean value of urea was $5.62 \pm 0.20 \mathrm{mmol} / \mathrm{I}$ which obtained from 540 animals irrespective of sex and age. The range was from 3-14 mmol/I. Moderate overall mean value was 5.10 $\pm 0.20 \mathrm{mmol} / \mathrm{I}$ obtained during moderate ambient temperature period. The findings of present study were similar to the observations of $[6 ; 7 ; 8 ; 9]$ in goats; and lower than the reportings of $[10 ; 11 ; 12]$ in goats. Some situations like dehydration or renal failure may produce increase of serum urea [13].

\subsubsection{Effect of hot and cold ambient temperature on serum urea:}

The mean value of urea was significantly $(\mathrm{p} \leq 0.05)$ higher during hot and lower during cold ambient temperature periods in comparison to overall moderate mean value. The result was in accordance with the reports of [14] in sheep; [15] and [16] in camel. Environmental stress can influence the urea cycle in hepatocytes [17], thereby causing profound effect during very hot and very cold conditions [18].

\subsubsection{Effect of sex on serum urea:}

The mean values in all the ambient temperature periods were significantly $(p \leq 0.05)$ higher in male than female animals. [19] observed higher serum urea in male than female sheep. However, $[7 ; 20 ; 21 ; 22 ; 23]$ did not observe sex effect in goats.

\subsubsection{Effect of age on serum urea:}

Age effect showed a significant $(\mathrm{p} \leq 0.05)$ increase in the mean values being lowest in the animals of 510 months of age. Earlier workers also reported the similar effect of age on serum urea values in goats [7;20; $21 ; 22 ; 23 ; 24$ ]. [3] did not observe significant $(\mathrm{p} \leq 0.05)$ effect of age. [19] observed significant age effect in sheep.

\subsection{Creatinine}

The overall mean value of creatinine was $94.97 \pm 2.90 \mu \mathrm{mol} / \mathrm{l}$ which was obtained from 540 animals irrespective of sex and age. The range was 55-153 $\mu \mathrm{mol} / \mathrm{l}$. Moderate overall mean value was $83.23 \pm 2.94 \mu \mathrm{mol} / 1$ which was obtained during moderate ambient temperature period.

The range and overall mean values in present studies were more or less similar to the values given by earlier workers in healthy goats viz. $[3 ; 7 ; 8 ; 11 ; 20 ; 25 ; 26 ; 27 ; 28]$ and higher than that published by [22] and [12]. The normal values of blood constituents can be affected by age, sex, breed, nutrition and other factors [3]. Creatine undergoes no catabolic reaction other than decomposition to creatinine [29].

\subsubsection{Effect of hot and cold ambient temperatures on serum creatinine:}

The mean value of creatinine was significantly $(\mathrm{p} \leq 0.05)$ higher during hot and non significantly higher $(\mathrm{p}>0.05)$ during cold ambient temperature periods in comparison to overall moderate mean value. These results are well supported by earlier findings in camel [16] and sheep [30]. Higher serum creatinine concentration in hot ambient period could be because of higher metabolic activity in liver and muscle due to environmental stress [3]. Cortisol [31] stimulated creatine metabolism in liver could result in higher creatinine formation. [3] asserted about creatinine levels as good indicators of stress since increased levels indicated catabolism. [32; 33] attributed higher serum creatinine in summer to decreased GFR and increased muscle breakdown or activity. 


\subsubsection{Effect of sex on serum creatinine:}

The mean values in all the ambient temperature periods were significantly $(\mathrm{p} \leq 0.05)$ higher in male animals than female animals. Concerning the effects of sex on serum creatinine in goats, contradictory results were obtained in the literature. In accordance with the results of present study, $[3 ; 7 ; 20 ; 28]$ showed that sex had significant influence with higher value in male goats. According to [25; 12], sex had no significant effect on serum creatinine in goats. [22] reported the significant increase in concentration of serum creatinine in females.

\subsubsection{Effect of age on serum creatinine:}

Age effect showed a significant $(\mathrm{p} \leq 0.05)$ increase in the mean values being lowest in the animals of 5 10 months of age. These results corroborated the earlier findings of $[7 ; 24 ; 25 ; 28]$ on goats. However, [3] in goats; [19] in sheep and [34] in camels. However, [35] in camels did not observe significant $(p \leq 0.05)$ effect of age.

IV. Tables

Table 1: Mean \pm SEM values of serum urea and creatinine in Marwari goats.

\begin{tabular}{|c|c|c|c|}
\hline S.No. & Effects & $\begin{array}{c}\text { Urea } \\
(\mathrm{mmol} / \mathrm{l})\end{array}$ & $\begin{array}{l}\text { Creatinine } \\
(\mu \mathrm{mol} / \mathrm{l})\end{array}$ \\
\hline 1. & Overall (540) & $5.62 \pm 0.20$ & $94.97 \pm 2.90$ \\
\hline 2. & Ambient temperature period & & \\
\hline (A) & $\begin{array}{l}\text { Moderate overall (180) } \\
\text { Sex }\end{array}$ & $5.10 \pm 0.20$ & $83.23 \pm 2.94$ \\
\hline (i) & Male $(90)$ & $6.07 \pm 0.31$ & $100.1 \pm 2.94$ \\
\hline (ii) & Female (90) & $4.14 \pm 0.14^{\mathrm{c}}$ & $66.3 \pm 3.00^{\mathrm{c}}$ \\
\hline II & Age & & \\
\hline (i) & $5-10$ months $(60)$ & $4.12 \pm 0.21$ & $65.3 \pm 2.20$ \\
\hline (ii) & $1-2$ Years $(60)$ & $5.05 \pm 0.20^{\mathrm{d}}$ & $80.3 \pm 3.50^{\mathrm{d}}$ \\
\hline (iii) & $2.5-4$ Years $(60)$ & $6.88 \pm 0.20^{\mathrm{d}}$ & $104.9 \pm 3.20^{\mathrm{d}}$ \\
\hline (B) & Hot overall (180) & $7.36 \pm 0.41^{b}$ & $113.0 \pm 3.05^{b}$ \\
\hline I & Sex & & \\
\hline (i) & Male (90) & $8.09 \pm 0.21$ & $136.0 \pm 3.10$ \\
\hline (ii) & Female (90) & $6.63 \pm 0.20^{\mathrm{c}}$ & $90.0 \pm 4.12^{\mathrm{c}}$ \\
\hline II & Age & & \\
\hline (i) & 5-10 months $(60)$ & $4.91 \pm 0.15$ & $85.5 \pm 3.50$ \\
\hline (ii) & $1-2$ Years $(60)$ & $6.90 \pm 0.28^{\mathrm{d}}$ & $105.7 \pm 4.00^{\mathrm{d}}$ \\
\hline (iii) & 2.5-4 Years $(60)$ & $10.61 \pm 0.25^{\mathrm{d}}$ & $148.4 \pm 4.20^{\mathrm{d}}$ \\
\hline (C) & Cold overall (180) & $4.48 \pm 0.05^{b}$ & $86.7 \pm 3.23^{a}$ \\
\hline I & Sex & & \\
\hline (i) & Male (90) & $4.9 \pm 0.04$ & $99.5 \pm 4.12$ \\
\hline (ii) & Female (90) & $3.9 \pm 0.06^{\mathrm{c}}$ & $73.9 \pm 3.16^{\mathrm{c}}$ \\
\hline II & Age & & \\
\hline (i) & 5-10 months $(60)$ & $3.9 \pm 0.06$ & $61.3 \pm 3.0$ \\
\hline (ii) & $1-2$ Years $(60)$ & $4.5 \pm 0.05^{\mathrm{d}}$ & $88.4 \pm 3.5^{\mathrm{d}}$ \\
\hline (iii) & 2.5-4 Years $(60)$ & $4.98 \pm 0.04^{\mathrm{d}}$ & $110.4 \pm 4.3^{\mathrm{d}}$ \\
\hline
\end{tabular}

(i) Figures in the parenthesis indicate number of goats.

(ii) In ambient temperature effect mean values of all the parameters of hot and cold ambient temperature periods have been compared with respective mean values of moderate temperature period.

(iii) Superscript ' $\mathrm{b}$ ' indicates a significant difference $(\mathrm{p} \leq 0.05)$ according to ambient temperatures.

(iv) In sex effect mean values of all parameters of female animals have been compared with respective mean values of male animals within ambient temperature.

(v) Superscript ' $\mathrm{c}$ ' indicates a significant $(\mathrm{p} \leq 0.05)$ difference according to sex within one ambient temperature period for a parameter.

(vi) In age effect mean values of all the parameters have been compared from 5-10 months age group.

(vii) Superscript ' $\mathrm{d}$ ' indicates a significant $(\mathrm{p} \leq 0.05)$ difference according to age within one ambient temperature period for a parameter.

\section{Conclusion}

It was concluded that liver functions were altered due to variation in ambient temperatures affecting the animals of both sexes and various age groups. Before interpreting the clinical data for any liver pathology based upon the parameters studied, certain factors like ambient temperature, sex and age should be considered. The result obtained in the present investigation will serve as a baseline for further research in the field of hepatic functions and enzymes. It will be helpful in clinical diagnosis in the Marwari goat during disease conditions or stress periods. 


\section{References}

[1] L S. Al-Bassam, S M. Azwai, O E. Abdouslam, S A. Al-lzzi, and A M. Al-Dawek, Effect of season on haematological parameters in clinically normal Llamas (Lama glama) raised in Libya, J. Camel Prac. Res., 14(2), 2007, $187-194$.

[2] A K. Kataria, and N Kataria, Stress induced changes in serum vitamin A and enzyme levels in Rathi calves. The Indian Cow, 2(5), 2005, 16-19.

[3] G S. Gottam, N Kataria, A K. Kataria, and L Singh, Serum metabolic profile of goats during stress, Veterinary Practitionar, 5(2), 2005, 156-158.

[4] H. Varley, Tests in liver and biliary tract disease, in Practical Clinical Biochemistry (Ed. 4), (New Delhi, CBS publishers, 1988) 158-467.

[5] G.W. Snedecor, and W.G. Cochran, (1967). In: Statistical Methods (Ed. 6), (New Delhi, Oxford \& IBH Publishing Co., 1967$) 45-83$.

[6] R R. Gray, C. Berg, and R. Windsor, Blood parameters of goats, Vet. Bullt., (12), 1988, 79-87.

[7] G K. Mbassa, and J S. Poulsen, Reference ranges for clinical chemical values in Danish Landrace goats, Small Rumin. Res., (2), 1993, 133-142.

[8] J.J. Kaneko, J.W. Harvey, and L.B. Michael, in Clinical Biochemistry of Domestic Animals (Ed. 5), (Harcourt Brace \& Company, Asia Pvt. Ltd., 1999) 327-352, 890-899.

[9] R.S. Charan, Filtered and excreted loads of some serum constituents in goats during moderate and extreme ambience. M.V.Sc. thesis, Rajasthan Agricultural University, Bikaner, Rajasthan, 2002.

[10] A. Castro, D S. Dhinsa, A S. Hoversland, and J. Metcalf, Serum proteins and protein electrophoretic pattern in normal Pygmy goats, Am. J. Vet. Res., (5), 1977a, 665-667.

[11] M.M. Benjamin, Outline of veterinary clinical pathology (Edition 3). (Iowa state university press. 1989) 55-75.

[12] P C. Behera, P C. Bisoi, B P. Mohanty, and G M. Panda, Clinically important serum constituents of black Bengal goats. Indian Vet. J. 78, 1993, 713-717.

[13] G.P. Carlson, Clinical Chemistry Tests, in Large Animal Internal Medicine (Edition 3) (Mosby Company, 2002$) 409-411$.

[14] N. Kataria, and A K. Kataria, Endocrine and metabolic responses of Marwari sheep in arid tract, Slov. Vet. Res., 43(3), 2006, 135142 .

[15] N. Kataria, A K. Kataria, V K. Agarwal, S L. Garg, and M S. Sahani, Filtered and excreted loads of urea in different climatic conditions and hydration states in dromedary, J. Camel Prac. Res., 8(2), 2001, $203-207$.

[16] N Kataria, A K. Kataria, V K. Agarwal, S L Garg, and M S. Sahani, Effect of long term dehydration on serum constituents in extreme climatic conditions in camel, Indian J. Physiol. Pharmacol., 46(2), 2002, 218 - 222.

[17] E. Wotron, Stress mechanisms and metabolism in animals (Ed. 4), (London, S \& A Baker Ltd., 1971) 35-37.

[18] S. Nazifi, M Saeb, E Rowghani, and K Kaveh, The influences of thermal stress on serum biochemical parameters of Iranian fat-tailed sheep and their correlation with triiodothyronine $\left(\mathrm{T}_{3}\right)$, thyroxine $\left(\mathrm{T}_{4}\right)$ and cortisol concentrations, Comparative Clinical Pathology, 12(3), 2003, 135-139.

[19] S. Sharma, and N Kataria, Studies on some nitrogenous metabolites of Magra sheep during famine conditions in Rajasthan, Indian Journal of Animal Research, 41(3), 2007, 208-211.

[20] A. Castro, D S. Dhinsa, A S, Hoversland, H. Malkus, C. Rosenthiel, and J. Metcalf, Serum biochemistry values in normal Pygmy goats. Am. J. Vet. Res., (12), 1977b, 2085-2087.

[21] J L. Deangelino, M M. Ishizuka, L. Ribeiro, T V Tucci, and E H. Birgel, Standard serum biochemical values of healthy goats reared in Saopaulo state, Braz., J.Vet.Res.Anim.Sci., (1), 1990, 91-97.

[22] A. Bennis, F. Farge, M. Kessabi, A. Hamliri, G P. Valdi, A G. Rico, and J P. Braun, Normal serum biochemical values of goats in the Moroccan Sahara, Revue de MedicineVeterinaire, (11), 1991, 831-837.

[23] E B. Otesile, and O B. Kasall, Effects of age and sex on serum proteins, urea nitrogen and transaminase concentration in Ethiopian highland sheep, Vet.Bullt., (9), 1993, 6253.

[24] D J. Kalita, and M. Mahapatra, Serum constituents and serum enzymes activities of Black Bengal kids, Inian Vet.J., 76, 1998, $1065-1066$.

[25] B. Sharma, J C. Biswas, and M Lal, Some biochemical parameters in serum of chegu goats. Indian J. Anim. Sci., 60(11), 1990, 1340-1341.

[26] G. Puri, and N Kataria, Creatinine clearance in Marwari goats during water deprivation and rehydration, Indian J. Anim. Hlth., 43(1), 2004, 1-5

[27] V Misra, J Kumar, A Pathak, D K. Johari, and S K. Garg, Biochemical analytes of cerebrospinal fluid and sera of goats, Indian J.Vet. Res., 17(2), 2008, 17-21.

[28] M. Sakha, M Shamesdini, and F Mohamad-zadeh, Serum Biochemistry Values in Raini Goat of Iran, The Internet Journal of Veterinary Medicine, 6(1), 2009, 27-31.

[29] D.R. Finco, Kidney function, in Clinical Biochemistry of Domestic Animals, 5th edn. (Harcourt Brace \& Company, Asia Pvt. Ltd., 1999) 440-484.

[30] R C. Meena, and N. Kataria, Effect of changes in environmental temperatures on glomerular filtration rate (GFR) in sheep. Indian J. Anim. Hlth., 42(2), 2003, 113-116.

[31] N Kataria, A K. Kataria, V K. Agarwal, S L. Garg, M S. Sahani, and R. Singh, Effect of water restriction on serum aldosterone and cortisol in dromedary camel during winter and summer, J. Camel Prac. Res., 7(1), 2000, 1-7.

[32] E.H. Coles, in Veterinary Clinical Pathology. (Ed. 4) (Phiiladelphia, WB Saunders Company, 1986) 114-202.

[33] N. Kataria, A K. Kataria,V K. Agarwal, S L. Garg, and M S. Sahani, Effect of seasonal dehydration on creatinine clearance in Indain dromedary camels, J. Camel Prac. Res., 10(2), 2003, 91-97.

[34] G H. Khadjeh, A. Mojabi, and M. Mayahi, Normal values of serum electrolytes and enzymes in iranian one humped camel (Camelus dromedaries), Indian Vet. J., 74, 1997, 384-387.

[35] A. Saeed, M M. Hussain, I A. Khan, G Chand, and R A. El-Yousuf, Effect of sex and age on blood biochemical profile in camel, J.Camel Prac.Res., 11(1), 2004, 73-77. 